\title{
7. The Endless Endings of Michelangelo Antonioni's Films
}

\author{
José Moure
}

Michelangelo Antonioni dreamed of:

\begin{abstract}
A film with a beginning, but maybe without an end. I have often wondered ... whether there should always be an ending to stories, whether literary, theatrical or cinematographic. A story which closes in on itself runs the risk of dying if another dimension is not provided, if one does not allow one's own time to be extended externally to where we are, we who are the protagonists of all stories. Where nothing ends. (Antonioni 1985, 224-225)
\end{abstract}

Built up around a disappearance or feeling of loss, and plotted along erratic, dissolving trajectories which efface or displace the initial emptiness without filling it, Antonioni's stories seem to resolve only in indecisiveness: the indecisiveness of a spiraling dénouement which is not a simple erasure or return to the point of departure. Instead, it "expresses the entropy, degradation and irreversibility of events" narrated in the course of the film, the irresolution of a dénouement in eclipse which "represents that ultimate point of a human being at last delivered from the negativity of projects, passions and human existence" (Bonitzer 1985, 101).

\section{The Endless Spiral}

From CRONACA DI UN AMORE (1950) to IDENTIFICAZIONE DI UNA DONNA (1982), most of Antonioni's films are resolved at the end by means of a "spiral" structure which, while tending to complete the film by way of a circular and centripetal movement of returning to the place of departure or a situation which is very near that of the beginning, leaves a certain number of questions unresolved and open, thus suspending the story in the void around which it has incessantly revolved, confronting the characters with repetition "for not having been able to escape the first time during the times that followed" (Amengual 1964, 56). The fundamental structure of Antonioni's films follows a cyclical model, which apparently brings the 
characters back to the starting point, place, or situation after an adventure that seems to have been pointless.

At the end of CRONACA DI UN AMORE, after the fatal accident of Paola's husband, the two lovers find themselves in a situation similar to that which separated them in the past after the accidental death of Guido's fiancée.

At the end of IL GRIDO (1957), after long meanderings in search of an impossible oblivion, Aldo comes back to his point of departure to die before Irma's eyes, by falling from the tower of the sugar refinery where he worked (in the last sequence, Aldo runs toward the factory while Irma runs after him, thus moving in the opposite direction of the first sequence).

At the end of L'AVventura (1960), after having replaced the girlfriend at Sandro's side, Claudia reaches the point where Anna gave up: that of infidelity, of love without love or illusions, and of compassion.

At the end of LA NOTTE (1961), after a day of wandering around which started with a visit to a dying friend, Lidia and Giovanni receive news that the friend in question has died. In the early morning, on the edge of a deserted park, they receive confirmation that their love, too, is dead, despite Giovanni's desperate attempt to embrace his wife, an act that serves as a reminder of the young nymphomaniac who threw herself at him in the clinic corridor.

At the end of The EcLIPSE (1962), the sentimental adventure between Vittoria and Piero seems to dissolve into the void of the places where they met, in the same way as the liaison between Vittoria and Riccardo exhausted itself in the latter's object-saturated apartment at the beginning of the film.

At the end of IL DESERTO ROsSo (1964), Giuliana is walking with her son near the petrol refinery where chimneys continue to spew yellow smoke, a scene which is reminiscent of the opening sequence.

At the end of BLOW Up (1966), while Thomas wanders around in the park and notices that the corpse has disappeared, he again encounters the group of mimes whom he ran into at the beginning of the film as he was leaving a night shelter, surrounded by tramps.

At the end of ZABRISKie PoInt (1970), after his plane trip across the desert, Mark, who is suspected of having murdered a policeman, is shot down without warning while bringing the stolen apparatus back to the place where he borrowed it.

At the end of The Passenger (1975), David Locke/Robertson, who feigned death, dies for real and fulfills the destiny he accepted at the start of the film by slipping into a corpse's skin. 
At the end of IDENTIFICAZIONE DI UNA DONNA, just as in the beginning of the film, Niccolo returns to Rome and prepares to write a new script: only this time, the subject will be science fiction.

Far from the story closing in on itself by providing a solution or response to the enigmas, interrogations, or expectations raised in the course of the film, the recurring, loop-like endings of Antonioni's films always leave something in suspense, as though the graph of the characters' circular trajectories eventually rolls up around itself in a never-ending loop, in a spiral-like dénouement which opens up unavoidably into the void of irresolution.

At the end of an Antonioni film, the intrigue is never really made clear, either because:

- The enigma (Anna's disappearance in L'AVVENTURA; the crime in the park in BLOW UP) at the center of the intrigue is unresolved, or the characters interrupt or forget their investigation in the process.

- The dénouement itself remains obscure from an anecdotal point of view (does the husband in CRONACA DI UN AMORE commit suicide because of a police report on his wife's infidelity, or did he really have an accident? In IL GRIDO, did Aldo throw himself from the top of the tower of the sugar refinery or, which is less probable, was he also the victim of an accident? For what reason and by whom was David Locke/ Robertson killed in The PAssenger?).

- The final scene, by its ambiguity, creates an endless suspension or total eclipse of the intrigue both as far as its meaning is concerned (does the fact that Claudia runs her fingers through Sandro's hair at the end of L'AVVEntura mean that his betrayal is forgiven? Does Giuliana's stroll with her son at the end of IL DESERTO ROsSo mean that she has been cured of her neurosis? When Thomas joins in the performance of the mime artists at the end of BLOW UP, does it mean that he has learned how to look at things?), as well as its virtual prolongation in the "after-film" (will Lidia leave Giovanni "after" LA notTE? What happens to Vittoria and Piero after the wasted opportunity of The ECLIPSE? After having failed in his IDENTIFICAZIONE DI UNA DONNA, will Niccolo make the science-fiction film that he plans to shoot?).

If a film by Antonioni is resolved, it is only by means of an irresolution without solution (because it is resolved by default in death, renunciation, compromise, uncertainty, or eclipse), suspending the characters' present in an endless expectation of a future without content. 


\section{An Ending in Eclipse}

Antonioni's films end on suspended dénouements (in suspension points and questions) which, far from opening the film into an indeterminate future or field of opportunity, marks the return of the story to a type of stalemate or nonresult where the unresolved intrigue (without mystery or solution, henceforth open but already deprived of potential, incomplete but almost fossilized) exhausts itself and settles into the void around which it has not ceased to revolve, brought to the surface of the world or the conscience of human beings by the erratic, dissolving trajectories of the characters, who were unable to fill that void.

The final sequence of an Antonioni film is only irresolute because the story's future has no solution. At the end of their adventure, the characters find themselves facing a reality which they cannot escape. There is nothing left for them to do except resign and sacrifice themselves either by:

- death, by slipping into the void - like Rosetta in LE AMICHE (1955), Aldo in IL GRIDO, Mark in ZABRISKIE PoINT, and David Locke/Robertson in The PAssenger;

- or in a less tragic way, by an act of renunciation - like Clara in LA SIGNORA SENZA CAMELIE (1953) who renounces her dignity as an actress, Clelia in LE AMICHE who renounces Carlo, Vittoria in THE ECLIPSE who renounces love, Thomas in BLOW UP who renounces grasping reality, and Niccolo in IDENTIFICAZIONE DI UNA DONNA who renounces his film;

- or by another type of survival with no illusions, i.e., compromising - like Claudia in L'AVVEnTURA who forgives Sandro, Lidia in LA NOTTE who gives in to Giovanni's pathetic embrace, and Giuliana in IL DESERTO Rosso who accepts life and reality as they are.

Thus, the end is the moment when a story unravels in a present which is decanted and free from past illusions and future inevitability. It is, of course, as much the mystery (the meaning of the past) as the outcome of the future that is being eclipsed at the same time as the story. All that remains is the tangible and opaque event recorded in the dimension of the precarious and the possible, stripped of all finality and without any indication of the meaning that should be attributed to the sequel.

From this point of view, the final sequence of The ECLIPSE provides the dénouement of a film by Antonioni with its most emblematic form and script: that of a wasted opportunity where past promises and future threats are decanted into the void of a space-time devoid of quality, in the process 


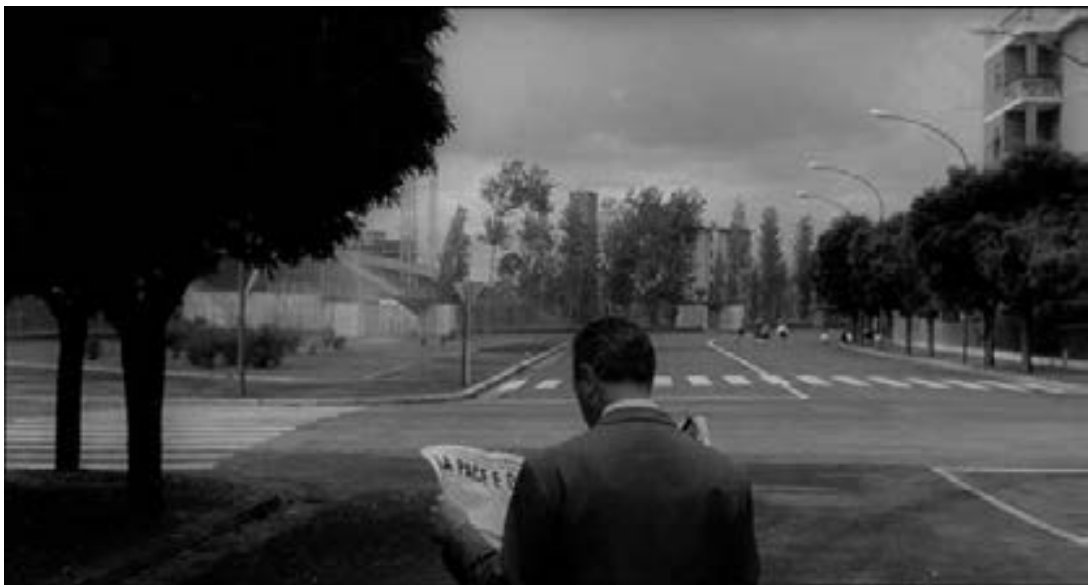

Fig. 7.1: The final sequence of THE ECLIPSE; "a wasted opportunity where past promises and future threats are decanted into the void of a space-time devoid of quality."

of reification, eclipsing characters and adventures, and presenting only the remains of a still-born sentimental story which, even before reaching its conclusion, freezes in revisiting the now empty spaces where rendezvous once took place; mineralizes in a suspension of what is to become; dissolves into a temporary darkening of the world; fades "behind an accumulation of micro-facts, notations and localisations which, while having as their initial aim to illustrate events as they develop [the rendez-vous neither Vittoria nor Piero will go to], eventually constituting a parallel world all by themselves" (Ollier 1981, 87), where future advance and past nostalgia are substituted for a participatory connection with a mysterious, suspended present.

After their lovemaking in the stockbroker's deserted offices has been interrupted by the ringing of a doorbell, Vittoria and Piero part tenderly:

Piero: Will we see one another tomorrow? (Vittoria nods yes.)

We'll see one another tomorrow and the day after.

Vittoria: And the day after and the day following that as well.

Piero: And the one after, too.

Vittoria: And tonight.

Piero: At eight. Same place.

They gaze at each other, then embrace with an almost desperate, anxious intensity. As Vittoria leaves, she looks at Piero one last time and disappears down the staircase. 
Piero returns to his office and closes the door; he is in a pensive mood. With robot-like gestures, he replaces all the receivers of the telephones he took off the hook. On the stairs, the young woman, who is also in a pensive mood, descends slowly; she stops and leans against the lift shaft which is being repaired. In his office, the young man, who still looks pensive, but who smiles faintly, sits down at his desk, when the telephones in an adjacent room as well as the one on his desk start ringing. He remains motionless, leans back against his chair, absorbed in his thoughts, his eyes closed, now serious (Piero is not seen again).

After having glanced up behind her, Vittoria (as though she could hear the ringing of the telephones or could still see Piero) continues her slow descent of the staircase. When she reaches the entrance door, after a last hesitation, she exits and starts walking quickly and with conviction. A female passer-by bumps into her and this ordinary incident is enough to interrupt her walking. She stops, pensively, in front of the iron curtain of a closed shop, turns around and looks at the tops of the trees outlined against the sky; then, after having glanced one last time toward the windows of Piero's office, she walks away and disappears, peacefully, almost serenely, with a faint, secretive smile on her lips (Vittoria is not seen again).

In the famous final sequence, from dusk to dark, all the places where Vittoria and Piero used to wait for and meet each other file past: the area around the crossroads and in front of the house under construction. In this final coda we are presented with an accumulation and a succession of shots of that which, until that point, constituted merely the diegetic background of the film and of Vittoria and Piero's amorous adventure.

An automatic sprinkler is on in the park; the nurse is pushing a pram. Piles of bricks, most of which are broken, are on the paving of a house under construction. A wooden barrier surrounds the house. A water-filled can has been left against the barrier; behind the barrier, the place under the tree (at the corner of the crossroads, in front of the pedestrian crossing) where Piero waited for and met with Vittoria, is now empty. Straw mats cover the house and metal scaffolding pipes are outlined against the sky. The sulky drawn by a horse trotting along passes along the deserted avenue; then, on the opposite sidewalk, we see the nurse with the pram; their shadows glide across the asphalt, dimly lit by a pale sun. Behind them, on the opposite side of the avenue, the deserted ticket offices and stadium pylons can be discerned. The pedestrian crossing leads to the house under construction; the man crosses and disappears. The leaves of the trees are stirred by the wind, and the deserted crossroads come into view (overall view, high-angle shot). The house under construction is on one of the corners of the crossroads; 
the sun has disappeared. The building-site can is filled with water; on its surface floats a piece of wood and the box of matches which Vittoria and Piero discarded there during their first meeting; a stream of water escapes from the pierced can and flows into the gutter. A woman waits at the trolleybus stop under the trees. A young woman (a prostitute?) waits for someone on a deserted corner of the crossroads. A trolleybus arrives, turns, and then stops with squeaking wheels. A woman and a man get off; the man opens a newspaper with the following headlines: "The atomic race" and "A precarious peace"; the man walks off. Children are playing; some run toward the sprinkler; a municipal worker closes the sprinkler; a few drops fall on the leaves. There is a shot of a modern building with balconies; followed by a close-up of one and then two of the balconies. A stadium pylon points toward the sky where a plane passes, leaving a long, white trail behind it. On the terrace of the white building, there are two tiny human figures: one stretches out her arm in front of her, toward the sky. The can with the piece of wood and box of matches is still leaking and the water is running slowly across the pavement. At first, one sees only the bottom part of an old man's face, then an eye wearing glasses and, finally, the head; he is motionless and seems to be looking at something, then walks away. We remain at the corner of the house under construction. The stadium pylons stand out against the cloudy sky, which is barely illuminated by the sun's rays which are disappearing below the horizon. There is a woman looking out from behind bars; a streetlamp is switched on. One of the avenues of the crossroads has lit streetlamps and cars, which have their headlights on; there is a shot of the house under construction with scaffolding pipes pointing toward the sky; another of the avenues has lit streetlamps. A trolleybus turns the corner of the house under construction; it stops and several people get off, their silhouettes moving away into the half-light. The corner of the crossroads is lit by a small streetlamp; toward the back, the house under construction is veiled by the now complete darkness of night; against the dark background of the horizon, points of light are coming from the streetlamps which line the avenue. A streetlamp, which diffuses an intense, luminous halo, fills the entire screen with a blinding light and seems to project the word: "END."

In this superb final sequence, Antonioni's cinema reaches the extreme point of the representation of the void toward which he has tended incessantly: places (or scenery) are emptied and exhausted in a fragmented space devoid of quality, which the camera revisits without any support of statement; characters suspend their adventure and withdraw to make way for a vanishing presence, indifferent movements and the fleeting faces of silent, anonymous figures; the story dissolves in the dispersion of heterogeneous 
versions of the present (or microfacts), pure events - detached from any diegetic purpose which finally drowns the diegesis in the world's suspended and extradiegetic time, a parallel world to that of the film, threatened, too, by nothingness, by a total and universal eclipse.

This extinction of the narrative - what Pascal Bonitzer called "a spool of nothing" $(1982,88)$ - is a type of probe which the filmmaker uses to create mystery; a mystery which unpicks and loosens the weft of the story, perhaps because, as Giorgio Agamben reminds us, "where there is mystery, there can be no story" $(2015,15)$. Or, simply because, as Antonioni admitted himself: "Any explication would be less interesting than mystery itself" $(1985,77)$.

Translated from the French by Naòmi Morgan.

\section{References and Further Reading}

Agamben, Giorgio. 2015. Le feu et le récit. Paris: Payot \& Rivages.

Amengual, Barthélemy. 1964. "Dimensions existentialistes de La notte." Études cinématographiques 18: 47-65.

Antonioni, Michelangelo. 1985. Rien que des mensonges. Translated by Sibylle Zavriew. Paris: Jean-Claude Lattès.

Bonitzer, Pascal. 1982. Le champ aveugle: Essais sur le cinéma. Paris: Gallimard.

—.1985. Décadrages: Peinture et cinéma. Paris: Editions de l'Etoile.

Ollier, Claude. 1981. Souvenirs écran. Paris: Gallimard. 